\title{
Islamic Economic Concept in Poverty Alleviation
}

\author{
Agussalim Rahman ${ }^{1}$, Siradjuddin $^{2}$ \\ *Corresponding Email: agus.stietdn@ gmail.com \\ ${ }^{1}$ Institute of Economic Science Tri Dharma Nusantara Makassar, Indonesia \\ ${ }^{2}$ Alauddin State Islamic University Makassar, Indonesia
}

\begin{abstract}
This study aims to describe the concept of Islamic economics in poverty alleviation. This research method is descriptive qualitative research using data sources from literature or library research (library research). The research approach uses a normative approach and a historical approach. The normative approach is used to examine the ideals of the Islamic Economic conception and then analyze how it is applied. Meanwhile, the historical approach is used to study empirical facts about poverty alleviation. The results showed that the stagnant distribution will cause inequality and social inequality. For this reason, the implementation of the zakat obligation is a very urgent need. The priority of poverty alleviation according to the concept of Islamic economics is to overcome the causes of poverty, namely improving the distribution of wealth. Zakat is the main instrument which is a solution to these various problems, especially in dealing with poverty and social inequality. In Islam, the state must create programs and facilities that can overcome the problem of poverty, guarantee a decent life for the poor and provide the economic means needed to become a source of livelihood for the poor. Islamic economics can be explored more deeply for the development of economics and its benefits in alleviating poverty.
\end{abstract}

Keywords: Islamic Economic Concept, Poverty, Poverty Alleviation

\section{Introduction}

Poverty is a condition in which humans experience difficulties in life because of the inability to meet their urgent basic needs such as food and drink, clothing and shelter. Poverty is a global problem of life faced by all human beings in every dynamic of civilization wherever and whenever (Singh \& Singh, 2008; Bhalla \& Lapeyre, 2016). The phenomenon of poverty is not only found in backward nations or developing nations but also in developed nations even though there is still poverty.According to an Islamic perspective, poverty can be seen in two dimensions, which is a test for humans to be patient and a threat from Satan to lead people to do evil. In QS. Al-Baqarah / 2: 155 and Qs Al-Baqarah / 2: 268. In a narration, Rasulullah SAW always prayed to be protected from the ugliness of wealth and poverty. Rasulullah saw, said: "O Allah, I take refuge in You from the slander of Hell and the torment of Hell, from the ugliness of wealth and poverty" in the Hadith History of Abu Daud No. 1319.

Pratama (2015) found that the cycle of poverty that occurs is due to the poor's lack of access to capital resources. The current economic system that does not take sides with the poor is suspected to be the cause of the difficulty in reducing poverty. Zakat is the only Islamic instrument used for the distribution of income and wealth. This proves that if the concept of Islamic Economics is well managed in accordance with the guidance of the Qur'an and Hadith and the state carries out its functions properly, trustfully and professionally, the implications

Copyright @ $\odot$ 2020, Journal of Asian Multicultural Research for Economy and Management Study, 
for reducing the number of poor families can be realized (Farooq, 2008; Choudhury \& Hassan, 2014 ).

Poverty is a malignant disease that will have a negative impact not only on individual life but also on social life, including the dimensions of aqidah (faith), behavior (moral), thought, civilization, household happiness and even human life in general (Ismaili, 2016; Salleh , 2017). Therefore Islam considers the phenomenon of poverty as a life problem that needs a solution. Even poverty is a disease that needs serious attention that must be immediately eradicated. After 1342 years of Hijriyah or 1302 years AD, various poverty alleviation programs have been carried out, a lot of budget has been spent to overcome the problem of poverty but no single country has been able to provide significant results in alleviating poverty. Based on these objective conditions, the researcher is interested in examining how Islamic economic concepts and models are able to create a just and prosperous society without poverty. The purpose of this research is to find out why the concept of Islamic Economics is able to create a society without poverty, especially in the era of the Caliph Umar bin Abdul Aziz government. With this study, the researcher will build a model of the Islamic Economy concept which contains complete Islamic syari'at guidance in poverty alleviation efforts. The usefulness of research is that finding a model of the Islamic economic conception in poverty alleviation can strengthen the main objective of Islamic Economics to provide benefits for life in the world and happiness (falah) in the afterlife so that it can be developed as a reference for the government / state in developing poverty alleviation programs.

\section{Methods}

This research is a descriptive qualitative research using data sources from literature or library research (library research). The reason the researchers used the literature method was because research problems could only be answered through library research and information or variable data under study, namely the Islamic economic concept of poverty available in literature with the main source coming from the Al-Qur'an and Hadith (Hadi, 2010). In supporting the availability of reading material, the researchers collected bibliographic tools (Zed, 2008) in the form of: reference books, textbooks, scientific journals, newsletters and magazines, newspapers and tabloids as well as Android-based applications / software such as the AlQur'an. and Translations, Haditsoft 2020 and the 9 Imam's Hadith Book Software (Pole Tis'ah). The research approach uses a normative approach and a historical approach (Hamzah, 2019). The normative approach is used to examine the ideals of the Islamic Economic conception and then analyze how it is applied. Meanwhile, the historical approach is used to study empirical facts about poverty alleviation that has occurred from the time of the Prophet Muhammad to the era of Caliph Umar bin Abdul Aziz.

\section{Results and Discussion}

Islamic economics has a complete concept of poverty alleviation. The concept consists of identification of the definition of poverty, measuring poverty, the essence of poverty, the causes of poverty, treatment of the poor (rights), the role of the state in alleviating poverty and the availability of various solutions in poverty alleviation based on the Qur'an and Hadith. This concept has been able to be realized during the reign of Islam (Khilafah Islamiyah) by running a government according to the Qur'an and Hadith, so that poverty alleviation has proven successful both during the reign of Caliph Umar bin Khattab (16-26 H / 638-637 AD) or during the reign of Caliph Umar bin Abdul Aziz in $91-101 \mathrm{H}$ or 718 - 720 AD which was marked by the absence of people who wanted to accept zakat as an indicator that all the people were well off. In just 2 years and 5 months the country will be prosperous and prosperous without any 
poor people. The results of research on the concept of Islamic economics in poverty alleviation, the authors describe through the following model:

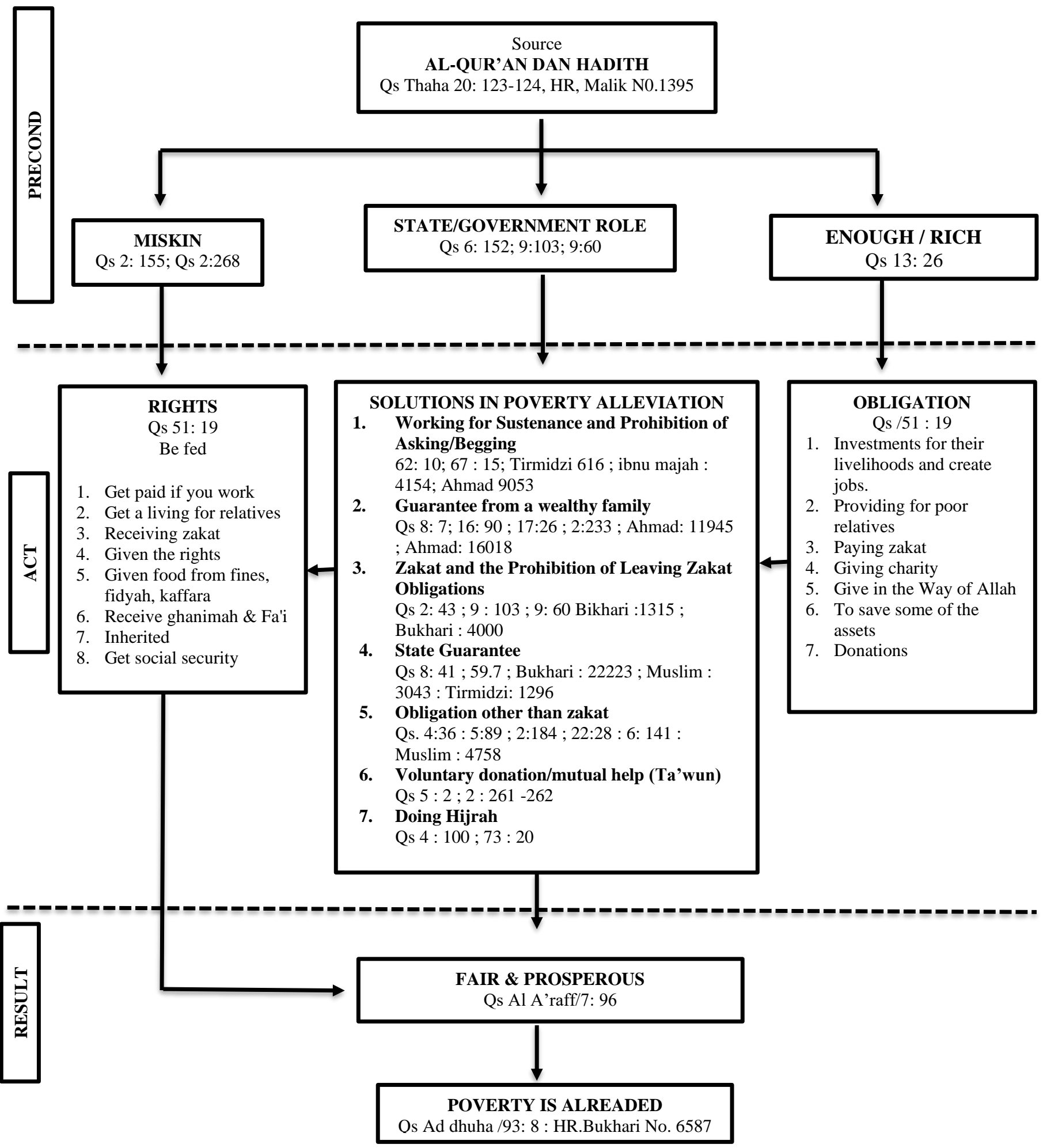

Figure 1. Poverty Alleviation Models According to Economic Concepts

Source: Agussalim Rahman, 2020

Qur'an and Hadith is a reference source of Islamic teachings containing guidance to behave for human beings in meeting the needs of life both as individuals (servants of God) and as part of

Copyright $@$ 2020, Journal of Asian Multicultural Research for Economy and Management Study, 
social society. Islamic economics is a science derived from the Qur'an and Hadith as a reference for the Muslim ummah in living their lives for the sake of their safety (not lost) in the world and in the hereafter. The teachings of Islam are based on guidance derived from Allah SWT.

Man in his life will appear different circumstances. Some of them are in possession of abundant wealth, some are well-off and some are wealthy, but they are unable to meet their basic needs or are in poverty. This difference is in accordance with the word of Allah swt in QS. An-Nahl / 16 : 71 that: "And Allah has preferred some of you over others in terms of rezki." And QS. Ar-Ra'd / 13: 26 which explains that God expands the provision (rich / sufficient) and It is God who narrows it to whomever He wants.

The condition of rich /sufficient and poor are both a test for human beings. The basis of this view is QS. Al-Baqaraah/2 : 155: "And we will surely test you with a little fear, hunger, lack of wealth, souls and fruits. Give good news to the patient." For those who have more spaciousness, Allah has given him the obligation to support his relatives and distribute some of his wealth to the needy, while for the poor have the right to help as God says in QS. AdzDzariyat/51 : 19 the translation: "And in their possessions there is a right for the poor who ask and the poor who do not get a share".

In the Islamic view, poverty is also a form of satanic temptation to damage human aqeedah. In Qs Al-Baqarah / 2: 268 Allah swt said: "Satan promises you with poverty and commands you to commit evil (niggardly)..."

Poverty is a malignant disease that will negatively affect not only the lives of individuals but also social life, including the dimensions of aqidah (faith), behavior (morals), thought, civilization, household happiness and even human life in general. In an effort to alleviate poverty, Islamic teachings require the presence of a state / government / caliph who plays a role to ensure the fulfillment of the rights of citizens, prepare regulations and provision of business facilities, manage zakat (ammil) and provide social security. With the rights of the poor and obligations for the rich and the role of the country, the solution to poverty alleviation regulated in the Qur'an and Hadith is formulated as follows:

\section{Work for Sustenance (Al-'amal) and the prohibition of beaning}

Islam commands people to work in search of a sumper livelihood as the word of Allah SWT, in QS. Al-Jumu'ah/62 : 10 ; Qs. Al-Mulk / 67 : 15, HR. Tirmidhi No. 616, HR. Ibn Maajah No. 4154 and the prohibition of so requesting as HR. Ahmad No. 9053 and Muslim Hr No. 1726.

\section{Life Insurance from a Capable Family}

Islam puts close relatives / relatives as people who should care and help each other's relatives. The strong must bear the weak. The rich must bear the poor. As in Qs Al-Anfal / 8 : 75 ; Qs An-Nahl /16 : 90 and Qs Al-Isra / 17 : 26, Qs Al-Baqarah / 2 : 233, HR. Ahmad : 11945 and 16018. It is the duty to provide for the poor relatives by able-can-do relatives, so that Islam has laid the foundation of the building of social solidarity to alleviate poverty.

\section{Paying Zakat and Prohibition of Leaving Zakat Obligations}

Zakat is the command of Allah which is the third Pillar of Islam. Zakat law fardhu ain for anyone who has qualified mandatory which is a major milestone of financial structure in Islam. After prayer, zakat is the most important religious obligation. There are many verses in the Qur'an and Hadith where Allah swt as the owner of this universe who ordered to give zakat in accordance with the terms of Nizab and Haul. He said, "O my people, worship God; al-

Copyright $@$ ( 2020, Journal of Asian Multicultural Research for Economy and Management Study, Under the license CC BY-SA 4.0 
Baqarah/2 : 43 ; Qs. at-Taubah/9 : 103 ; Narrated by. Bukhari No. 1315 and 4000 For Muslims who refuse to pay zakat for their property will get a painful punishment as god says in QS At Taubah/9: 34; Hr Ahmad No. 7247 ; Narrated by Tabhrani No. 4577 and Narrated by Ibn Maajah No. 1789.

Zakat which serves as an instrument that regulates the distribution of income and wealth. The stalling of distribution will lead to inequality and social inequality. Therefore, the implementation of zakat obligations is a very urgent need. There is no doubt that zakat is the main instrument that is the solution to various economic problems of the ummah, especially in dealing with the problem of poverty and social inequality.

\section{State Guarantee}

Every Islamic state or other country has wealth as a public property that is managed and used for the benefit of the state. For example, waqf for the public interest, mining, fisheries and marine resources, forest management and other natural resources. Allah swt said in Qs AlAnfal / 8: 41 ; Qs Al-Hasyr / 59 : 7 ; Narrated by. Bukhari No., 2223 and Muslim No. 3043. Management of waqaf by the country as hr. Sunan Tirmidhi No. 1296.

If Islamic cash sources are not able to meet the needs of the poor and no member of society personally cares about their fate then the government of a country must withdraw donations from the rich to simply cover the basic needs of the poor.

In Islam, the state must create programs and means that can overcome the problem of poverty, provide a guarantee of a decent life for the poor and provide the economic means needed to become a source of livelihood for the poor.

\section{Obligagtion other than Zakat}

In addition to zakat, there are also other obligations that must be fulfilled by a Muslim for various reasons. All of them are resources to provide assistance to the poor as well as a means of eliminating poverty. The obligations are among: first, the obligations of neighbors. In Qs An Nisa / 4: 36 Allah almighty commands us to do good to neighbors who are close to the far. The Prophet gave an example of how to do good to neighbors through Muslim HR No. 4758. Second, Sacrifice on Eid al-Adha as hr. Ad-Daruquthni No. 4698. Third, the penalty for violation of oath (kaffarah). As god says in Qs Al-Maidah / 5: 89). Fourth, Fine dhihar by feeding sixty poor people. Fifth, kaffarah fines. Sixth, fidyah for people can no longer afford to carry out the obligation of fasting Ramadan based on the word of God in Qs Al-Baqarah / $2: 184$. Seventh, Had is a fine because he has done something that is forbidden during ihram or also for performing Hajj tamattu' or hajj qiron and other violations. As God says in Qs AlMaidah/5:95 and Qs Al-Baqarah/2:196. In this verse contained the obligation by the Shari'a to provide food in the form of meat to the poor (Qs Al-Hajj / 22:28) Eighth, The right of crops at harvest that are not included in the zakat as Qs Al-An'am / 6: 141

The explanation of some verses and hadiths above emphasizes that one of the obligations of sharia is the existence of additional obligations other than zakat as a form of solidarity (takaful) for the rich in each region.

\section{Voluntary Donation (ta'wun)}

Islamic teachings form a noble person in the form of benefactors and dare to sacrifice that is to give more than requested, spend more than required, can even give without being asked even in difficult situations and conditions. As God says in Qs Al-Maidah 15:2 and Qs Al-Baqarah 12: $261-262$ 


\section{Doing Hijrah}

If you have not obtained adequate sources of livelihood then Islam teaches to do hijrah in order to walk in search of rezki on the earth as in Qs An Nisa/4: 100 and Qs Al-Muzammil / 73 : 20. What a noble teaching of Islam. If all the commandments of Allah and His Messenger are carried out in a kaffah with full faith and piety, then Allah will bring down his blessing from heaven and grow his blessing from the earth by making the life of man just and prosperous full of blessings as promised by Allah in QS Al-A'raf / 7:96: "If the people of the cities believed and feared, we would certainly bestow upon them blessings from heaven and earth...". If people already feel justice and prosperity, the distribution of wealth is already running then by itself poverty can be eliminated in people's lives.

In fact, Allah swt has created man and all beings at the same time provide a means to meet his needs. It is not for God to create a creature, and then leave him alone. Allah swt in Qs Rum/30: 40 said the translation: "It was God who created you, then gave you rezki...". In QS Qs. alA'raf/7: 10 Allah swt said that man placed on earth equipped with his livelihood, : "We have set you in the earth and made for you livelihood in the land. Little do you give thanks." Thus Allah created his creatures including people on the earth equipped with a means of fulfilling the needs) enough to live his life. This is the precondition created by Allah SWT so that if man lives his life in accordance with his Shari'a guidance then people can avoid poverty.

Therefore, the occurrence of poverty is not due to insufficient resources to meet the needs of human life. Poverty is not due to scarcity of resources, but because of human error in resource management that results in inequality in the distribution of resources. So the main factor that causes poverty is human error in managing livelihoods and inequality in the distribution of resources (wealth).

The Qur'an revealed by Allah SWT to the Prophet Muhammad SAW contains the teachings of Islam that is plenary and also dynamic following the development of human civilization. Islamic teachings contain all the clues about how people live their lives including when facing poverty problems.

During the Islamic rule (Khilafah Islamiyah) by running the government in accordance with the Qur'an and hadith, poverty alleviation proved successfully realized both during the reign of Caliph Umar bin Khattab and in the era of Caliph Umar bin Abdul Aziz in 91 - $101 \mathrm{H}$ or 718 $720 \mathrm{AD}$ which was marked by the absence of people who would receive zakat as an indicator of all the people had enough. In just 2 years and 5 months to make the country prosperous and prosperous without any poor people. (Shallabi, 2014). According to Qardhawi (2014), when Umar ibn Abdul Aziz became caliph, the country was in a state of fairness and prosperity and poverty was gone. Caliph Umar bin Abdul Aziz's reign covered an area of 15 million km2, stretching from the eastern sides of Kufah, Basrah and Khurazan to the west side in Andalusia Spain and North Africa with a population of about 62 million people or the equivalent of 39 countries today.

According to Suryawati (2005) poverty is divided into four forms, namely absolute poverty, relative poverty, cultural poverty and structural poverty. Absolute poverty refers to a consistent standard of poverty. Not affected by time and space. It is absolutely in a poor state. Relative poverty is a poverty standard that can change depending on the assumed poverty standard that is applied. Cultural poverty is a condition of poverty caused by certain factors inherent in a person and the habits of a society. For example, laziness to work, low work ethic, tendency to live extravagantly, less respect for time, and low interest in achievement. An interesting phenomenon today is that people perceive poverty as a profession like beggars do. Cultural 
poverty is generally self-induced. Structural poverty is a condition of poverty that is caused by factors related to other human actions, such as colonialism, authoritarian and militaristic governance, rampant corruption and collusion, unfair economic policies, and a world economy that is more favorable to certain groups. The main cause of structural poverty is exploitation between humans. In addition, there is also a form of natural poverty, namely poverty caused by natural factors, both related to human resources and natural resources that surround it, for example physically and mentally disabled people, low ownership and access to factors of production. , climatic factors, soil fertility, and natural disasters.

Islamic economics has various solutions to alleviate poverty based on the Qur'an and Hadith, including: (1) work, (2) guarantees from capable relatives, (3) zakat, (4) state guarantees, (5) obligations other than zakat and (6) voluntary donations / help to help (Qardhawi, 2002).

Shihab (1998) states that the Koran obliges every Muslim to participate in reducing poverty according to his abilities as QS. Al-Thalaq / 65: 7. Zakat in an Islamic economy is a potential source of funds to advance social welfare. Zakat is closely related to social, moral and economic dimensions. In the social dimension, zakat is a social obligation that has the character of worship because zakat is imposed on individual assets aimed at society in order to fulfill their needs and alleviate poverty. In the moral dimension, zakat erodes the greed and greed of the rich. Meanwhile, in the economic dimension, zakat prevents the accumulation of wealth in a certain number of people. (Mannan, 1993).

Rozalinda (2016) said that apart from being an obligation for Muslims, through zakat, the Koran makes it a responsibility for fellow Muslims to help help. Thus Islam builds relationships between the rich and the poor on the basis of justice, equality and brotherhood. The faqir does not envy the rich, the rich do not oppress the poor. Rich and poor people feel that they are siblings (Qardahwi, 2002).

One of the solutions to the poverty problem can be understood from the viewpoint of Patmawati (2006) who analyzes the role of zakat in reducing poverty and income inequality in the state of Selangor, Malaysia, using the Lorenz curve and the Gini coefficient, finding that the bottom $10 \%$ of society enjoy $10 \%$. society's wealth due to zakat. This figure increases by $0.4 \%$ when zakat transfers occur. Meanwhile, the top $10 \%$ of society enjoy wealth by $32 \%$ or down from $35.97 \%$ in the position before the zakat transfer. Patmawati concluded that the gap between groups could be reduced and zakat was able to reduce poor families in Selangor.

\section{Conclusion}

The concept of Islamic Economics contains complete guidelines based on the Al-Qur'an and Hadith that are able to create a just and prosperous society without poverty. Islamic teachings oblige the presence of the State / government to guarantee the implementation of community rights and obligations, provide regulations, manage zakat (amil) and provide social security. Poverty alleviation solutions based on the Al-Qur'an and Hadith which consist of: orders to work for sustenance and prohibitions on asking for money, life insurance from a capable family, zakat and prohibition on leaving the obligation to give zakat, state guarantees, gifts other than zakat, Please help (ta 'wun) and perform the hijrah. The priority of poverty alleviation according to the concept of Islamic economics is to overcome the causes of poverty, namely improving the distribution of wealth so that poverty can be eliminated by itself.

\section{References}

Bhalla, A. S., \& Lapeyre, F. (2016). Poverty and exclusion in a global world. springer. 
Choudhury, M. A., \& Hassan, A. (2014). The challenge in poverty alleviation: role of Islamic microfinance and social capital. Humanomics, Emerald Group Publishing.

Farooq, M. O. (2008). The challenge of poverty and the poverty of Islamic economics. Journal of Islamic Economics, Banking and Finance, 4(2), 35-58.

Hadi, S. (2010). Metodologi Research. Yogyakarta: Fakultas Psikologi, UGM.

Hamzah, A. (2019). Metode Penelitian Kepustakaan (Library Research). Jakarta: Litera Nusantara.

Ismaili, H. (2016). Concept of social justice in Islam (a study of Hamka's perspective in Tafsir al-Azhar). Thesis, UIN Walisongo.

Mannan, M. A. (1993). Ekonomi Islam: Teori dan Praktek. Yogyakarta: PT. Dana Bhakti Wakaf.

Patmawati, (2006). Economic Role of Zakat in Reducing Income inequality and Poverty in Selangor. Dissertation, Selangor: Universiti Putra Malaya.

Pratama, Y. C. (2015). Peran zakat dalam penanggulangan kemiskinan (Studi kasus: Program zakat produktif pada Badan Amil Zakat Nasional). Tauhidinomics, 1(1), 93-104.

Qardhawi, Y. (2002). Teologi Kemiskinan: Doktrin Dasar dan Solusi Islam atas Problem Kemiskinan. Yogyakarta: Mitra Pustaka.

Qardhawi, Y. (2014). Problematika Rekonstruksi Ushul Fiqih. Al-Fiqh Al-Islâmî bayn AlAshâlah wa At-Tajdîd, Tasikmalaya.

Rozalinda, E. I. T. (2016). Aplikasi pada Aktivitas Ekonomi. Jakarta: Rajawali Pers.

Salleh, M. S. (2017). Contemporary Vision of Poverty and Islamic Strategy for Poverty Alleviation. SAGE Open, 7(2), 2158244017697153.

Shallabi, A. M. (2014). Perjalanan Hidup Khalifah yang Agung Umar bin Abdul Aziz Ulama dan Pemimpin Yang Adil. Judul asli: al-Khalifah ar-Rasyid wal maslaha kabiir, Penerjemah: Izzudin Karimi, Jakarta: Darul Haq.

Shihab, Q. (1998). Wawasan Al-Qur'an. Jakarta: Mizan.

Singh, A. R., \& Singh, S. A. (2008). Diseases of poverty and lifestyle, well-being and human development. Mens Sana Monographs, 6(1), 187.

Suryawati, C. (2005). Memahami kemiskinan secara multidimensional. Jurnal Manajemen Pelayanan Kesehatan, 8(03).

Zed, M. (2008). Metode Penelitian Kepustakaan, Jakarta: Yayasan Obor. 